\title{
"BUSINESS AS UNUSUAL": PANDEMIC CONCENTRATION OF EXECUTIVE POWERS IN CROATIA
}

\begin{abstract}
Faced with the Covid-19 pandemic, countries around the globe responded with a wide range of special measures. Whereas some of them resorted to their constitutional emergency rules, others opted to act through legislation. The author argues that the effects of the legislative approach to the epidemic in Croatia actually resemble the state of an emergency in the proper sense of the word, although the authorities try to present the whole case as a situation of "legal normalcy". More precisely, the author claims that in practice the adopted model produces concentration of power in the executive branch far beyond what one could expect in ordinary times. To prove that, the author analyses the Croatian legal anti-epidemic framework through several elements (declaration of emergency, law-making powers, overview of executive emergency actions, parliamentary sittings). Finally, the author argues that the constitutional state of natural disaster in Croatia should have been proclaimed.
\end{abstract}

Key words: Covid-19, pandemic, epidemic, states of emergency, Croatia.

\section{INTRODUCTION}

Emergencies create consequences that not only affect people's private lives and general social or economic relations, but also constitutional law. According to its characteristics, the present Covid-19 pandemic is by no means an exception to that. At the same time, concrete legal consequences of the present emergency vary from country to country and whereas a number of them decided to resort to their constitutionally prescribed rules of conduct foreseen for grave crises, others opted to combat the threat through legislatively framed tools of reaction. ${ }^{1}$

\footnotetext{
* Associate Professor, Zagreb University, Faculty of Law; e-mail: dgardase@pravo.hr

1 For a general comparative overview thereof, I refer, for instance, to: Grogan, J., Power and the COVID-19 Pandemic - Introduction \& List of Country Reports, VerfBlog,
} 
Croatia belongs to the latter category and in this paper I will first try to describe how this was done. The main point I wish to stress here is that, by rejecting the constitutional and instead choosing the legislative framework, Croatian authorities avoided to formally proclaim the case as the situation of a constitutional "emergency" ("severe natural disaster" 2 ). This way, and despite some significant amendments to the special legislation, they decided to pursue their anti-epidemic actions through processes of deliberation and decision-making that, constitutionally speaking, resemble those undertaken in ordinary times.

This strategical decision, however, came with significant costs. As I will try to argue, the legislative approach the Government, backed up by its parliamentary majority, opted for actually resulted in consequences that are far away from those that may and should be expected in ordinary times. For that purpose, I will focus on one particular consequence that arose from the Croatian approach to the epidemic: an unusual concentration of powers in the hands of the executive branch of Government. In other words, I will try to show that this concentration of powers, in its main characteristics, is more close to the real type of a constitutional emergency. In addition to this, I will try to show that a more appropriate approach would be to qualify the whole case as a situation which perfectly fits the category of a "severe natural disaster", foreseen in Article 17 of the Croatian Constitution. ${ }^{3}$

2021/2/22, (https://verfassungsblog.de/power-and-the-covid-19-pandemic/, DOI: $10.17176 / 20210222-154018-0)$. For a previous version of the same symposium, see: Grogan, J., Introduction \& List of Country Reports, VerfBlog, 2020/4/06, (https:// verfassungsblog.de/introduction-list-of-country-reports/, DOI: 10.17176/20200417182630-0).

2 Article 17 of the Croatian Constitution. For the English translation of the Croatian Constitution, (https://www.constituteproject.org/constitution/Croatia_2013?lang=en, 15. 4. 2021).

3 For a similar discussion, see, for instance: Greene, A., States should declare a State of Emergency using Article 15 ECHR to confront the Coronavirus Pandemic, (https:// strasbourgobservers.com/2020/04/01/states-should-declare-a-state-of-emergencyusing-article-15-echr-to-confront-the-coronavirus-pandemic/, 13. 4. 2021); Scheinin, M., COVID-19 Symposium: To Derogate or Not to Derogate?, (http://opiniojuris. org/2020/04/06/covid-19-symposium-to-derogate-or-not-to-derogate/, 13. 4. 2021). For other analyses on the Croatian example, see: Gardašević, Đ., Izvanredna stanja, "velike prirodne nepogode" i promjene Ustava Republike Hrvatske, in: Bačić, A. (ed.), 2021, Ustavne promjene i političke nagodbe - Republika Hrvatska između ustavne demokracije i populizma, Zagreb, Hrvatska akademija znanosti i umjetnosti - Znanstveno vijeće za državnu upravu, pravosuđe i vladavinu prava, pp. 249-275; Gardašević, Đ., Pandemija kao "stanje velike prirodne nepogode" i Ustav Republike Hrvatske, in: Barbić, J. (ed.), 2021, Primjena prava za vrijeme pandemije Covid-19, Zagreb, Hrvatska akademija znanosti i umjetnosti - Znanstveno vijeće za državnu upravu, pravosuđe i vladavinu prava, pp. 23-45. 


\section{General Remarks}

Two principal issues seem worth of attention before I proceed to the specifics of the Croatian legal approach to the Covid-19 epidemic.

The first is to give some remarks on the difficulty of providing a proper definition of an emergency. This problem is by no means a novelty and it may be useful here to, at least briefly, notice how it was appearing throughout history to this day. At the same time, I believe this conclusion has an important normative value in understanding the fact that most states, when faced with the present epidemic, decided to readjust their legal tools according to the characteristics of the arising threat. As I will show, Croatia in this respect opted for an approach through amendments to its anti-epidemic laws.

The second issue I address here is related to a possible scheme of legal consequences emergencies create in the field of constitutional law. This issue has an important technical value in my further evaluation of the Croatian case, focus in which is on one of those consequences: concentration of "emergency" power in the hands of the executive.

I will now address those two issues in turn.

\subsection{THE PROBLEM OF A PROPER DEFINITION OF EMERGENCY}

It is not my intention here to provide a general overview of the existing constitutional classifications of emergencies in comparative terms but rather to point to some problems of definition in theoretical terms. The problem is of a general nature and is not restrained to the present pandemic. Nevertheless, I believe that the following introductory observations might be quite helpful in attempting to perhaps better understand what we are dealing now when faced with the actual case.

To start with, one should be aware that definitional problems surrounding the notion of emergency are by no means a novelty. From that point of view, it is well known that already the classical authors, one way or another, discussed the issue of the difficulty to both define emergencies and to foresee their legal consequences. Thus, for instance, we find it in the writings related to the "prerogative" (John Locke) ${ }^{4}$, the "dictatorship"

4 J. Locke thus famously argued that the legislators are "not being able to foresee, and provide by laws, for all that may be useful to the community". In his world, it is the executive (the prerogative) which in emergencies must act for the public good, without the prescription in law, or sometimes even against it. See: Locke, J., 1824, The Works of John Locke in Nine Volumes $12^{\text {th }}$ ed., London, Rivington, Vol. 4, Chapter XIV: Of Prerogative, paras. 159, 160. (http://oll.libertyfund.org/title/763, 15. 4. 2021). 
(Jean Jacques Rousseau) ${ }^{5}$, the "government" (Alexander Hamilton ${ }^{6}$ and James Madison ${ }^{7}$ ), the "exception" (Carl Schmitt) ${ }^{8}$ and the "constitutional dictatorship" (Clinton Rossiter). ${ }^{9}$

With such a rich classical background, it may not be surprising that modern states also differ in their particular approaches to defining constitutional emergency regimes. However, among the more recent writers, Oren Gross and Fionnuala Ní Aoláin in that respect for instance quite generally conclude the following:

Review of the existing classifications of states of emergency reveals a substantial degree of vagueness, ambiguity, and overlap between the different categories as may be expected in light of the definitional difficulties which inhere in the term 'emergency'. Some of the key terms used in this context, such as 'danger' and 'imminent threat', are broad enough to make the choice between the possible categories mostly a political issue. ${ }^{10}$

Definitional problems regarding emergencies are also visible with other contemporary authors who, for instance, point that it is difficult to properly define the state of exception and its relationship towards the

5 On his part, J. J. Rousseau claimed: “[...] as there are at thousand occurrences for which the legislator has not provided, it is a very necessary part of foresight to perceive that everything cannot be foreseen." See: Rousseau, J. J., 1951, The Social Contract, the Hafner Library of Classics, New York, Hafner Publishing Company, Book IV, Chapter VI: Of the Dictatorship.

6 A. Hamilton pointed that powers needed for the common defense "ought to exist without limitation, because it is impossible to foresee or define the extent and variety of national exigencies, or the correspondent extent and variety of the means which may be necessary to satisfy them." See: Hamilton, A., The Necessity of a Government as Energetic as the One Proposed to the Preservation of the Union, Federalist, No. 23, December 18, 1787.

7 J. Madison asked if "the establishment of a government, adequate to the national happiness, was the end at which" the Articles of Confederation "themselves originally aimed, and to which they ought, as insufficient means, to have been sacrificed". See: Madison, J., The Powers of the Convention to Form a Mixed Government Examined and Sustained, Federalist, No. 40, January 18, 1788.

8 C. Schmitt, in the most reductionist way, claimed that in the case of an extreme peril "the most guidance the constitution can provide is to indicate who can act in such a case" and concluded that this is where the definition of a sovereign actually resides. See: Schmitt, C., 2005, Political Theology, Four Chapters on the Concept of Sovereignty, Chicago, University of Chicago Press.

9 Thus, C. L. Rossiter warned that "Of course, it is not possible to foresee in detail the conditions which will obtain in a period of emergency". But, as an answer to Schmitt, he also insisted that, as much as possible, "all emergency action should have some basis in the law". See: Rossiter, C. L., 1948, Constitutional Dictatorship - Crisis Government in the Modern Democracies, Princeton, Princeton University Press.

10 Gross, O., Ní Aoláin, F., 2006, Law in Times of Crisis - Emergency Powers in Theory and Practice, New York, Cambridge University Press, p. 45. 
notions of civil war or rebellion. ${ }^{11}$ Or, that categories of war, invasion, civil war and terrorism make it hard to put the phenomenon of modern international terrorism into the right box. ${ }^{12} \mathrm{Or}$, that modern international terrorism is neither a war nor crime, but that it represents an emergency of a sui generis origin. ${ }^{13}$

An interesting point regarding the problem of definition of emergencies is offered by Eric Posner and Adrian Vermeule, who claim that "emergencies lie on a continuum, or sliding scale." According to them, "at one end are routine domestic policies adopted in peacetime" while at the other "are policies adopted in times of full-blown crisis". And somewhere "in between are situations in which government policy is unusually consequential for foreign policy or for national security, but where some or all of the features that describe a full-blown emergency are absent." ${ }^{\prime 4}$

Comparably, Michel Rosenfeld distinguishes between times of crisis, ordinary times and times of stress. For him, "times of stress are neither ordinary times nor times of crisis" because "in the context of a crisis, be it military, economic, social, or natural, the head of government may be entitled to proclaim exceptional powers and to suspend constitutional rights, including political rights". Moreover, "in an acute crisis, the polity is singularly focused on survival, and all other political concerns and objectives recede into the background." On the other hand, "in ordinary times, the polity can readily absorb the full impact of the give and take of everyday politics, and constitutional rights ought to be protected to their fullest possible extent." Consequently, Rosenfeld argues the following:

Times of stress differ from those of crisis primarily in terms of the severity, intensity, and duration of the respective threats involved. The line between the two may be difficult to draw, but a less severe, less intense, and more durable threat is likely to give rise to times of stress whereas a severe, intense, concentrated threat, of relatively shorter duration, is likely to provoke a crisis. For example, a foreign military invasion or a widespread domestic insurrection is likely to provoke a crisis. On the other hand, the aftermath of the terrorist attacks against New York City on

11 Agamben, G., 2005, State of Exception, Chicago, London, The University of Chicago Press, p. 2.

12 Ferejohn, J., Pasquino, P., 2004, The Law of the Exception: A Typology of Emergency Powers, International Journal of Constitutional Law, Vol. 2, No. 2, pp. 231-232.

13 Ackerman, B., 2006, Before the Next Attack - Preserving Civil Liberties in an Age of Terrorism, New Haven, London, Yale University Press; Ackerman, B., 2004, The Emergency Constitution, Yale Law Journal, 113, p. 1029; Posner, R. A., 2006, Not a Suicide Pact - The Constitution in a Time of National Emergency, Oxford University Press, New York.

14 Posner, E. A., Vermeule, A., 2007, Terror in the Balance - Security, Liberty and the Courts, New York, Oxford University Press, p. 42. 
September $11^{\text {th }}$, 2001 - which involved threats, perceived threats, launching a "war on terror" fought mainly in far away countries, arrest and detention of potential terrorists, but no further terrorist attack on the United States as of the time of this writing - has produced times of stress rather than times of crisis. ${ }^{15}$

One could go on and on with further theoretical views on emergencies. But it is obvious that the issue of their definition still occupies constitutional lawyers and other social scientists of today, just like it occupied their historical predecessors. What is also worth noticing is that the actual understanding of the Covid-19 danger, although globally perceived as a serious, perhaps even an existential threat of a sui generis origin ${ }^{16}$, also reveals significant differences in legal approaches various countries opted for. Whereas some states thereof acted under the umbrella of their constitutional emergency provisions, other decided to activate, or amend, their special anti-epidemic legislation.

As I will further show, Croatia belongs to the latter category. The fact that the Croatian authorities avoided to refer to emergency constitutional rules thus confirms their conclusion that the epidemic does not qualify for a full-blown crisis, but rather to some type of the time of stress. Or, as Kim Lane Scheppele would put it, in Croatia the epidemic may be seen as a kind of a "small emergency", or one of those "problems that are deemed worthy of exceptional solutions, but are simultaneously deemed too minor to warrant a full-fledged reassessment of constitutional structures and constitutional aspirations." 17

\subsection{EMERGENCIES AND THEIR CONSTITUTIONAL CONSEQUENCES}

There are two major constitutional consequences that are created by emergencies: those affecting the domain of specific powers among the branches of government and those inflicting upon the status of protected rights and freedoms. Moreover, those two types of consequences generally may stand in a mutual relationship.

Within the classical theorists of emergency concepts, such a point may be observed with Rossiter. Rossiter stressed that one of the three

15 Rosenfeld, M., 2006, Judicial Balancing in Times of Stress: Comparing the American, British, and Israeli Approaches to the War on Terror, Cardozo Law Review, Vol. 27:5, pp. 2084-2085. See also: Rosenfeld, M., A Pluralist Theory of Political Rights in Times of Stress, in: Sadurski, W., (ed.), 2006, Political Rights under Stress in $21^{\text {st }}$ Century Europe, Oxford, New York, Oxford University Press, pp. 26-27.

16 See: UN News: COVID-19 pandemic, an 'unprecedented wake-up call' for all inhabitants of Mother Earth, (https://news.un.org/en/story/2020/04/1062322, 15. 4. 2020).

17 Scheppele, K. L., 2006, Small Emergencies, Georgia Law Review, 40, p. 835. 
"fundamental facts" underlying the rationale of the principle of constitutional dictatorship is that "in time of crisis a democratic, constitutional government must be temporarily altered to whatever degree is necessary to overcome the peril and restore normal conditions". In addition, it means that "this alteration invariably involves government of a stronger character; that is, the government will have more power and the people fewer rights". ${ }^{18}$

Similarly, among the more contemporary authors, Emmanuel Gross, for example, claims: "In times of emergency, the Executive branch is vested with wider administrative powers than in times of peace; however, these powers inherently infringe upon the traditional scope of protection given to the individual's rights and freedoms. "19

However, beyond these generally posited elements, emergencies in their full potential unveil other consequences, or constitutive questions, that are worthy of attention. Thus, for instance, John Ferejohn and Pasquale Pasquino differ between various constitutional provisions concerning emergency powers ("EP"). According to them, those relate to the aspects of declaration of emergency powers, their exercise, reestablishment of normality, control of the effects of the emergency and specific emergency measures. Or, as they put it, four dimensions have to be considered here: "(1) who declares emergency; (2) who exercises these powers; (3) who declares the end of the emergency; and (4) who can interfere with or adjudicate legal questions connected with the decisions made under EP."20

18 This being the second, Rossiter in sum proposes three of his fundamental facts. The first is that "the complex system of government of the democratic, constitutional state is essentially designed to function under normal, peaceful conditions, and is often unequal to the exigencies of a great national crisis". And the third is that "this strong government, which in some instances might become an outright dictatorship, can have no other purposes than the preservation of the independence of the state, the maintenance of the existing constitutional order, and the defense of the political and social liberties of the people." Rossiter, C. L., 1948, pp. 5-7.

19 Gross. E., 2008, How to Justify an Emergency Regime and Preserve Civil Liberties in Times of Terrorism, South Carolina Journal of International Law and Business, Vol. 5, Issue 1, p. 20. See also: Tushnet, M. (ed.), 2005, The Constitution in Wartime Beyond Alarmism and Complacency, Duke, London, Duke University Press, pp. 3-4. See also: Özbudun, E., Turhan, M., 1995, Emergency Powers, European Commission for Democracy Through Law, Council of Europe Publishing, p. 4. In their elaboration on the conceptual structure of emergency powers and the relationship between the "norm" and the "exception" to it, J. Ferejohn and P. Pasquino stress that constitutional norms in the material sense of the notion "mostly concern the separation of powers, i.e., the competences of the branches of the government and citizens' rights." See: Ferejohn, J., Pasquino, P., 2004, The Law of the Exception: A Typology of Emergency Powers, International Journal of Constitutional Law, Vol. 2, No. 2, p. 221.

20 Ferejohn, J., Pasquino, P., 2004, p. 230. 
Moreover, William Scheuerman points that „At a minimum, a model of emergency power needs to explain which institution can declare an emergency, which institution can end it, what new powers are available during it, which legal protections remain inviolate, and by what standards courts review emergency power." ${ }^{21}$

In their view on the same issue, Gross and Ní Aoláin offer several consequences of emergencies. Those may be: "suspension of certain individual rights and freedoms", "expansion of (national) government powers and concentration of such powers in the hands of the executive branch", including "the ability of the executive to engage in the process of law-making", the effects on "the principle of federalism", possible prohibitions of "any change or modification of the constitution itself during an emergency", or prohibition of dissolution of the legislature during an emergency. ${ }^{22}$ And apart from the legal consequences of emergencies in the strict sense of the word, those two authors also generally focus on procedural issues of the authority to declare an emergency and checks and balances. ${ }^{23}$

Carving out from the preceding doctrinal proposals as to what constitutes proper elements indispensable for evaluating an emergency, in the following part I will focus on one particular issue thereof: the concentration of executive authority. In other words, my general aim here is to show that the specific Croatian approach to the present Covid-19 epidemic, despite the official rhetoric of constitutional normalcy, ends up in strengthened and concentrated executive powers that may give room for concern. I will address those concerns later in the conclusion.

And for the purposes of my analysis, by the executive here I mean specifically the Government alone, without the involvement of the President of the Republic. This, on the other hand, means that other branches are somehow, to a greater or a lesser extent, put aside and given either a secondary, and supportive, role (the Parliament and the Constitutional Court) or no role at all (the President of the Republic).

For that purpose, I will try to show how the concentration of executive powers affected the position of the Parliament, the President of the Republic, the Constitutional Court and regional (local) bodies with the authority to act in the actual epidemic.

21 Scheuerman, W. E., 2006, Emergency Powers and the Rule of Law After 9/11, The Journal of Political Philosophy, Vol. 14, No. 1, p. 74.

22 Gross, O., Ní Aoláin, F., 2006, pp. 58-62.

23 Ibid., pp. 54-58 and 62-66. 


\section{The Croatian Approach to the Covid-19 EPIDEMIC}

I now turn to the specifics of the Croatian approach to the present epidemic. I will first present the legal framework under which the authorities have so far dealt with the crisis and try to point to the fact that they opted for a legislative approach, rather than for invoking emergency constitutional provisions. This is followed by a short description of examples of political rhetoric in which, in contrast, one may observe that the Government was not restrained to proclaim the threat as a global and national phenomenon without a precedent. Obviously, those two qualifications (strictly legal and rhetorically political) of the same issue stand in opposition. Finally, I will give an overview of the problem of concentration of power in the Croatian case, as seen through the lenses of relevant criteria, namely: the authority to declare and terminate the state of epidemic, emergency "law-making" powers, parliamentary overview of executive emergency actions and the issue of parliamentary sittings.

At the same time, to this analysis I will add the relevant standings of the Croatian Constitutional Court regarding particular issues I will examine. I should stress here that the Court so far delivered a number of decisions concerning the Covid-19 legislative and other special measures, starting from September 2020. In an overwhelming majority of cases, the Court showed a large level of deference to the executive (and thus to parliamentary majority) argumentation, which is visible both in terms of legal interpretation it deployed and in the fact that only two of the specific anti-epidemic measures by now were struck down in a constitutional review.

Apart from the abstract constitutional review of the laws on civil protection system and protection from infectious diseases I present below in reference to specific problems that review touched upon, the Constitutional Court in separate cases also reviewed some concrete anti-epidemic measures. These measures, in sum, included the ban on crossing the state borders, prohibition of leaving the place of residence and restrictions on public assemblies, work of shops and markets, provision of some other services, sport and cultural activities, as well as on cemetery ceremonies. Here the Court concluded that the applicants did not substantiate their claims and that the contested measures expired prior to the Court's decision. It also referred to similar measures undertaken in other countries 
and concluded that, from that point of view in the Croatian context, the measures were appropriate and necessary. ${ }^{24}$

On the other hand, the Court upheld the measure imposing a mandatory wearing of face protection masks, stressing that it derived from the state's positive obligation to protect health and that it was thus rational and necessary. 25

In the first decision in which it struck down the measure imposed, the Court concluded that prohibition of work of shops, markets and similar businesses on Sundays exclusively was not necessary because the Government did not prove that Sundays were most frequent days for shoppers and because it was applied only once the general March 2020 lockdown had already ended. ${ }^{26}$

Apart from that, the Court also stuck down some parts of the antiepidemic amendments to the Parliament's Standing Orders. ${ }^{27}$ I will come back to that decision in the subsequent chapter dealing with the issue of parliamentary sittings. ${ }^{28}$

24 See the following decisions of the Croatian Constitutional Court: U-II-1312/2020, U-II-2027/2020, U-II-1373/2020, September $14^{\text {th }} 2020$. However, those cases were not decided unanimously. Most importantly, the dissenting judges here argued that the Court should have acted in due time, while the contested measures were still in force, and that the Court did not have to wait to review the cases on the motion of the applicants, because it had its own power to take them into consideration ex officio. The Court also upheld the measure of restricting public gatherings in three more recent decisions. See: Decision of the Croatian Constitutional Court: U-II-364/2021, February 23 ${ }^{\text {rd }}$ 2021; Decision of the Croatian Constitutional Court: U-II-5709/2020, U-II-5788/2020, February $23^{\text {rd }} 2021$; Decision of the Croatian Constitutional Court: U-II-6087/2020, U-II-6160/2020, February 23 ${ }^{\text {rd }} 2021$. Decisions of the Croatian Constitutional Court (in Croatian) are available at: https://sljeme.usud.hr/usud/praksaw.nsf, 20. 4. 2021.

25 Decision of the Croatian Constitutional Court: U-II-3170/2020, September $14^{\text {th }}$ 2020. The three dissenters in substance pointed that the measure was imposed only months after the actual outbreak of the epidemic, thus concluding that it was neither rational nor necessary.

26 Decision of the Croatian Constitutional Court: U-II-2379/2020, September $14^{\text {th }}$ 2020. Here, one dissenter argued that the case should have been (procedurally) rejected because the applicants did not substantiate their claim in the first place. Another dissenter objected that the Court this time took the case on its own motion and that, thus, this represented an ungrounded judicial activism. The three concurring judges, however, argued that the Court should have applied Article 17 of the Constitution (thus, accepting that a real constitutionally defined emergency existed) and criticized the Court's interpretation of the elements of appropriateness and necessity of the measure at stake.

27 Decision of the Croatian Constitutional Court: U-I-4208/2020, October $20^{\text {th }} 2020$.

28 For a wider description of the case-law of the Croatian Constitutional Court I reference to the COVID-19 pandemic, see: Gardasevic, Dj., Activism of the Croatian 


\subsection{LEGAL STRATEGY OF "NORMALCY" UNDER "SPECIAL CIRCUMSTANCES"}

Croatia belongs to those states that, in the face of the Covid-19 epidemic, decided to address the threat through readjusted legislation. This means, at the same time, that the public authorities avoided to invoke the constitutional emergency regime designed, among other things, for the case of a "severe natural disaster". Since this particular decision of the ruling parliamentary majority created a decisive strategic approach to the whole case, I will briefly explain the constitutional model rejected and the legislative model opted for.

The Croatian Constitution contains two principal articles foreseen for crisis conditions. Article 17 regulates restrictions of fundamental rights and freedoms and may be applied in cases of war, immediate threat to the independence and unity of the State or in the event of severe natural disasters. Should one of the said situations occur, the primary power to decide on restrictions is vested in the two-thirds majority of all the representatives in the Parliament. If the Parliament is, however, unable to convene, the same power transfers to the President of the Republic, but only at the proposal of the Government and with the counter-signature of the Prime Minister. Moreover, in all cases involving emergency restrictions of rights, special standards of prohibition of discrimination and proportionality principle apply. At the same time, Constitution commands that constitutional guarantees on some specific rights may not be restricted, even in the case of an immediate threat to the existence of the State. ${ }^{29}$ Apart from that, Article 101 of the Constitution gives the authority to the President of the Republic to enact emergency decrees, in cases of war, immediate threat to the independence, unity and existence of the State or when the state bodies cannot regularly perform their constitutional duties. Countersignature of the Prime Minister to the emergency decrees is required, save for the war situation and the Parliament must approve the decrees as soon as it is able to convene. ${ }^{30}$ Additionally, the Constitutional Court has the power to decide on constitutionality of emergency measures. As I already pointed, none of the two mentioned constitutional provisions was put in action in reference to the Covid-19 case. Consequently, the twothirds majority in the Parliament was from the beginning set aside and the

Constitutional Court and COVID-19: A Bridge Too Far, in: Belov, M., (ed.), Courts and Judicial Activism Under Crisis Conditions - Policy Making in a Time of Illiberalism and Emergency Constitutionalism, Routledge (forthcoming on September $23^{\text {rd }}$ 2021).

29 Article 17 of the Croatian Constitution.

30 Article 101 of the Croatian Constitution. 
executive proceeded to act under the alternative version: the legislatively conferred powers.

Moreover, the Croatian Constitutional Court in that context completely deferred to the executive, backed up by its majority in the Parliament, that the state of a "severe natural disaster" should not have been proclaimed. According to the Court, the decision whether to invoke the emergency regime under Article 17 of the Constitution or to continue to apply Article 16 as in ordinary times ${ }^{31}$ was an issue to be resolved exclusively by the Parliament itself and not the Court. ${ }^{32}$ However, this position was strongly criticized by three dissenting judges. ${ }^{33}$

In contrast, the entirety of anti-epidemic measures in Croatia is enacted on the basis of two laws, specially amended after the epidemic hit the country in March 2020. On one hand, Article 22.a of the Law on the Civil Protection System introduced a new definition of the situation, describing it, in short, as the case of the "special circumstances" involving an unpredictable or uncontrollable event or state endangering the lives

31 Article 16 of the Constitution prescribes the rule for restrictions of rights and freedoms in the following way: "Freedoms and rights may only be restricted by law in order to protect freedoms and rights of others, public order, public morality and health. Every restriction of freedoms or rights shall be proportional to the nature of the necessity for restriction in each individual case." On the other hand, Article 83 of the Constitution commands that laws regulating rights and freedoms the Parliament must be enacted by a majority of all of its representatives.

32 Decision of the Croatian Constitutional Court: U-I-1372/2020, September $14^{\text {th }} 2020$. In this decision the Court upheld the constitutionality of the amendments to both the Law on the Civil Protection System and the Infectious Diseases Protection Law. It did the same in a later case. See: Decision of the Croatian Constitutional Court: U-I5918/2020, U-I-5919, February $3^{\text {rd }} 2021$. The Court confirmed the same standing in two other cases. In the first, it reviewed the "epidemic" amendments to the Law on Local Elections. Those amendments allowed for postponement of local elections under provision almost identical to the "special circumstances" clause in Article 22.a of the Law on the Civil Protection System. See: Decision of the Croatian Constitutional Court: U-I-1925/2020, September $14^{\text {th }} 2020$. And in the second case, the Court affirmed that yet another similar legal provision allows the Headquarters to regulate working hours in catering businesses during the epidemic. See: Decision of the Croatian Constitutional Court: U-I-2162/2020, September $14^{\text {th }} 2020$. I give an overview of the "special circumstances" clause in the following text. For an approach defending the position that a state of severe natural disaster as constitutionally prescribed should not have been proclaimed, see: Omejec, J., 2020, Primjena Europske konvencije o ljudskim pravima u doba koronavirusa, Informator - tjednik za pravna $i$ ekonomska pitanja, 68, No. 6622, pp. 1-14.

33 The dissenters in this part advocated for activation of Article 17 of the Constitution, stressing that the existence of a "severe natural disaster" was an obvious fact arising from the mere facts arising from the global situation related to the COVID-19 pandemic. See: Decision of the Croatian Constitutional Court: U-I-1372/2020, September $14^{\text {th }} 2020$. 
and health of citizens. Additionally, the National Civil Protection Headquarters as the body empowered to act in special circumstances ${ }^{34}$ has the authority to "render decisions and guidelines to be implemented by the civil protection authorities of the local and regional governments". Moreover, those "decisions" and "guidelines" must be enacted for the purpose of protecting the lives and health of citizens [...]" ${ }^{35}$ On the other hand, Article 47 of the Infectious Diseases Protection Law provides for a range of concrete anti-epidemic measures. Among those are, for instance, measures of disinfections and setting up a quarantine, travel bans and restrictions of movement, isolation and self-isolation etc. But the same provision also contains a general clause, allowing for adoption of "other necessary measures". All those measures may be enacted by the Minister of Health or by the previously mentioned Headquarters. In practice all the measures are adopted exclusively by the Headquarters and not the Minister. The Law, however, directs that the Headquarters issues its decisions under direct control of the Government and the usual course in Croatia is that the Headquarters adopts the measures only following sessions of the Government, in which the concrete anti-epidemic action is first discussed. The Constitutional Court, on its part, accepted the constitutionality of the adopted legislative model. In fact, it concluded that the present epidemic, by its characteristics, perfectly fit the definition of "special circumstances" and that the National Headquarters was chosen as an adequate body with appropriate powers to deal with it. ${ }^{36}$

There is one important additional point that needs to be made here, suggesting that the anti-epidemic legal strategy the Government decided for in the Covid-19 conditions actually led to its concentration of powers, but in a rather special way. This point emerges from a more scrutinized view on yet another relevant legislative solution the Government actually had at its disposal, but which it did not invoke. More precisely, even prior

34 It should, however, be stressed that the said National Civil Protection Headquarters was already, within the version of the same Law in force prior to the epidemic, defined as the body with the authority to act in cases requiring civil protection measures.

35 For another description of the Croatian legislative response to the COVID-19 threat, see also: Selanec, Nika Bačić: Croatia's Response to COVID-19: On Legal Form and Constitutional Safeguards in Times of Pandemic, VerfBlog, 2020/5/09, (https://verfassungsblog.de/croatias-response-to-covid-19-on-legal-form-and-constitutional-safeguards-in-times-of-pandemic/, DOI: 10.17176/20200509-133132-0); Selanec, Nika Bačić: COVID-19 and the Rule of Law in Croatia: Majoritarian or Constitutional Democracy?, VerfBlog, 2021/4/27, (https://verfassungsblog.de/covid-19-and-the-rule-of-law-in-croatia-majoritarian-or-constitutional-democracy/, DOI: 10.17176/20210427-101228-0).

36 Decision of the Croatian Constitutional Court: U-I-1372/2020, September $14^{\text {th }} 2020$. 
to the present epidemic the Law on the Civil Protection System foresaw a special state of "catastrophe", the notion whose definition highly resembles the one given through the March 2020 amendments to the concept of "special circumstances". ${ }^{37}$ The state of catastrophe, and its termination, is declared by the Government ${ }^{38}$ which, thereafter, assumes the power of directing actions of other civil protection bodies. ${ }^{39}$ Finally, in such a scenario, the National Civil Protection Headquarters is headed directly by the Prime Minister, or another minister under his authority. ${ }^{40}$ What is missing, however, is a provision which would provide the Government with, alone or through the National Headquarters, the law-making powers. Obviously, this was the underlying reason for the March 2020 epidemic amendments to the Law on the Civil Protection System. Practical consequence of a new model, thus, is that the Government now may directly influence the law-making process and, at the same time, argue that the primary responsibility for efficiency of adopted "decisions and guidelines" rests with the said Headquarters and not the Government itself. Interestingly, though, in its later exposition before the Constitutional Court, the Government claimed, without further explanation, that the actual Cov$i d-19$ situation did not fit the definition of a "catastrophe", but rather that of "special circumstances". The majority in the Court did not object to that standing, but it was criticized in dissenting opinions. ${ }^{41}$

\subsection{POLITICAL RHETORIC OF "AN UNPRECEDENTED CRISIS"}

As I stressed, in face of the Covid-19 epidemic Croatian authorities decided to avoid activation of constitutional emergency clauses and opted to act through modifications of special laws. The underlying normative justification for such a position is obvious: the epidemic does not amount to a "severe natural disaster" that would require extraordinary processes of parliamentary, and possibly further executive, deliberations. In short,

37 In fact, in the relevant part, the Law defines a state of catastrophe as a state created by a natural event, which, by its magnitude, intensity and unpredictability endangers health and lives of a greater number of people. Article 3 of the Law on the Civil Protection System.

38 Ibid., Article 54.

39 Ibid., Articles 9 and 14.

40 Ibid., Article 22.

41 Decision of the Croatian Constitutional Court: U-I-1372/2020, September $14^{\text {th }} 2020$. In this case, the Constitutional Court upheld the constitutionality of the Law on the Civil Protection System. The dissenters, however, pointed that the activation of the "special circumstances" model amounted to nothing less than the definition of the state of a "severe natural disaster" from Article 17 of the Constitution and criticized that the same article was not used. 
the situation was qualified as "special circumstances", albeit not of such a magnitude that would lead to an outright emergency, as regulated in Article 17 of the Constitution.

From that point of view, however, one should notice that this significantly diverged from official statements given in public. Proofs for that may be found already in the early stages of the epidemic. Thus, for instance, in its speech given at the session of the Government in late March 2020, the Croatian Prime Minister stressed the following: "This is a kind of a crisis without a precedent. No one ever has faced such challenges. According to some estimations, two billion of people in the world are today in the regime of limited movement. This has never happened." 42 Similar statements of the same Prime Minister continued in the fall of the last year when he dramatically warned: "The entire COVID-19 crisis represents a reset of everything [...] We live in a year without a precedent. No one in the world has experienced that. No one has faced such a grave crisis and everything changes from the roots. We are not aware of consequences on the functioning of any aspect of social life." 43 The same type of qualification by the Prime Minister persists to this day. Thus, presenting the governmental plan of special recovery measures in April 2021, he insisted that the "pandemic of corona virus represents a health peril without precedent, that caused an economic crisis of a magnitude unseen from the Second World War." 44

A more formal frame for the rhetoric underlying the existence of special circumstances is visible in the Governmental bill on the amendments to the Infectious Diseases Protection Law, submitted to the Parliament in April 2020. The bill contains an express reference to a "new legal situation" caused by the apparition of Covid-19, which has not previously been foreseen. The arguments for such a claim were that cumulative declarations of epidemic in Croatia and pandemic in the world necessitated adoption of legislative measures appropriate to the gravity and urgency

42 The speech of the Croatian Prime Minister given at the $220^{\text {th }}$ session of the Government, held on March $26^{\text {th }} 2020$. Available (in Croatian) at: https://vlada.gov.hr/ vijesti/ovo-je-kriza-bez-presedana-nastavljamo-s-primjerenim-mjerama-da-zaustavimo-pandemiju/29087, 15. 4. 2021.

43 Statement given by the Croatian Prime Minister during the session of the Parliament held on November $3^{\text {rd }} 2020$. Available (in Croatian) at: https://www.novilist.hr/novosti/hrvatska/plenkovic-zivimo-u-godini-bez-presedana-sve-se-mijenja-iz-korijena/, 15. 4. 2021.

44 Statement given by the Croatian Prime Minister during the session of the Parliament held on April $14^{\text {th }}$ 2021. Available (in Croatian) at: https://lider.media/poslovna-scena/hrvatska/plenkovic-u-saboru-brani-nacionalni-plan-oporavka-i-otpornosti-136245, 15. 4. 2021. 
of the situation. Moreover, the circumstances of the epidemic were qualified as implying "rapid and unpredictable changes" as well as presenting a "permanent danger from an exponential rise of the number of people infected". 45

And in its submission to the Constitutional Court, defending constitutionality of the Covid-19 special legislation, the Government further pursued the rhetoric that the epidemic did not amount to a "natural disaster" but rather to its vision of "special circumstances". Firmly denying that Article 17 of the Constitution should have been put in action, it repeated that the whole state was for the first time faced with a new legal situation, unforeseen in the laws adopted prior to the epidemic. As I already pointed, the majority in the Court accepted that position. ${ }^{46}$

\subsection{CONCENTRATION OF POWERS IN ACTION}

In its entirety, the concentration of powers problem in the Croatian dealings with the present epidemic can be examined from three separate perspectives.

The first is found in the 2020 amendments to the Law on the Civil Protection System that empowered the National Civil Protection Headquarters to render anti-epidemic decisions and guidelines and prescribed that those are further implemented by local and regional civil protection authorities. Such an outcome sounds reasonable when one recognizes the true nature of the epidemic as a natural phenomenon that does not respect administratively drawn borders. In Croatia, this became obvious already at the very beginning of the epidemic when both the threatening circumstances and particular, independently taken actions of certain local civil protection authorities warned that a more unified strategy was indispensable. ${ }^{47}$ Moreover, the country in the same period was struck by

45 The Bill on the Amendments to the Infectious Diseases Protection Law, submitted to the Croatian Parliament on April $9^{\text {th }} 2020$. Available (in Croatian) at: https://sabor. $\mathrm{hr} /$ sites/default/files/uploads/sabor/2020-04-09/183402/PZ_921.pdf, 15. 4. 2021.

Decision of the Croatian Constitutional Court: U-I-1372/2020, September $14^{\text {th }} 2020$.

47 The need for a more centralized decision-making process in enacting anti-epidemic measures was offered by the Government as the main reason for enacting the March 2020 amendments to the Law on the Civil Protection System. In its bill thereof, the Government stressed that the epidemic activated both the National Civil Protection Headquarters and local (regional) civil protection headquarters, but that the overall circumstances required a more unified approach that would be attained by giving the central body a new power of issuing its decisions and guidelines. See: The Bill on the Amendments to the Law on the Civil Protection System, submitted to the Croatian Parliament on March $17^{\text {th }} 2020$. Available (in Croatian) at: https://www.sabor.hr/ 
a series of deadly earthquakes. This, in addition, revealed the seriousness of the whole situation. The complete view to that aspect of the problem, however, shows that the adopted scheme of such a vertical concentration of powers is not totally rigid. In fact, regional authorities in Croatia may alone enact specific anti-epidemic measures reserved for their respective territories. Nonetheless, the competence of the National Civil Protection Headquarters to decide otherwise still remains. I have already pointed that vertical concentration of powers makes one of possible consequences of emergencies and the described facts only confirm that this element also is present in the Croatian case. ${ }^{48}$

The second perspective to the concentration of powers issue is related to the position of the President of the Republic. As I showed in my description of articles 17 and 101 of the Croatian Constitution, the President indeed may have a role in emergency actions, including those arising out of a severe natural disaster, but his powers are in that respect greatly restricted by the need to obtain a countersignature by the Prime Minister. Moreover, the President in such circumstances may act only if the Parliament is unable to effectively meet or if state bodies cannot regularly perform their constitutional duties. Of course, and having in mind that the present epidemic still may escalate, both the inability of the Parliament or other, vaguely defined, state bodies to execute their duties remains a possibility. So far, this has not happened and the actual President, on his own

sites/default/files/uploads/sabor/2020-03-17/183002/PZ_860.pdf, 15. 4. 2021. This, however, being the first step in concentrating the "special circumstances" powers, the second followed with the amendments to the Infectious Diseases Protection Law a month later. This time, and stressing the gravity and urgency of the situation, the Government proposed the "general legislative model of handling the crisis", the one in which "the National Civil Protection Headquarters acts and decides in cooperation with Ministry of Health and Croatian Institute for Public Health, under direct control of the Government of the Republic of Croatia." See: The Bill on the Amendments to the Infectious Diseases Protection Law, submitted to the Croatian Parliament on April $9^{\text {th }}$ 2020. Available (in Croatian) at: https://sabor.hr/sites/default/files/uploads/ sabor/2020-04-09/183402/PZ_921.pdf, 15. 4. 2021.

48 The vertical concentration of powers in emergencies is definitely one of the dimensions of the problem, recognized both in the classical and modern theory. Thus, for instance, C. L. Rossiter pointed that "federalism, regionalism, municipal freedom, local self-government - all of these are institutional devices whereby the total power of the state has been further divided and subdivided in the name of liberty." Nevertheless, he also noted the following: "But federalism and local self-government, be they important as in the United States or Switzerland, or rather less significant as in France, present distinct barriers to effective crisis action, and in a great emergency they will be broken down. Constitutional dictatorship must mean a concentration of power, no matter how it is divided." See: Rossiter, C. L., 1948, p. 289. See also: Gross, O., Ní Aoláin, F., 2006, p. 60. 
part, has not tried to invoke his emergency prerogatives. Therefore, at the time of my writing, this particular aspect of the relationship between the separation and concentration of powers is not yet relevant. ${ }^{49}$

The third perspective concerning the concentration of powers problem is related to the position of the legislative body. From that point, some more in depth analysis of the executive concentration of powers reality in the Croatian context is possible and in the following subchapters I will try to describe the facts of the case. Technically, the specific position of the Croatian parliament in the context of the present epidemic may be reviewed from several aspects. The first is related to the problem of authority to declare and terminate the state of epidemic, the second to law-making powers, the third to parliamentary overview of executive emergency actions and the fourth to parliamentary sittings.

\subsubsection{Authority to declare and terminate the state of epidemic}

Having in mind the classical Roman views on the republican institution of "dictator" and following the bitter experiences of World War II and the collapse of the Weimar Republic, both Rossiter and Friedrich argued that emergencies should not go unregulated. One of the elements making their concept of a "constitutional dictatorship" is that the authority to decide on introduction and termination of an emergency, as a distinctively delicate issue, must be separated from the authority to enact emergency measures. With Rossiter, for instance, we find it within his eleven criteria of constitutional dictatorship, more precisely in the second (" 2 . the decision to institute a constitutional dictatorship should never be in the hands of the man or men who will constitute the dictator. In other words, no constitutional dictator should be self-appointed") and the ninth ("9. The decision to terminate a constitutional dictatorship, like the decision to institute one, should never be in the hands of the man or men who constitute the dictator."). ${ }^{50}$

49 However, the actual President of the Republic has from the start of the epidemic criticized the strategy of not proclaiming the state of a natural disaster according to Article 17 of the Croatian Constitution. In his view, the situation required that the Parliament should have been deciding on restrictions of constitutional rights and freedoms and he has continuously in public been criticizing the legislative model. See, for instance: https://www.telegram.hr/politika-kriminal/milanovic-se-danas-prvi-put-ozbiljno-suprotstavio-vladinoj-odluci-zapelo-je-na-ljudskim-sloboda$\mathrm{ma} /$, 16. 4. 2021.

50 For those criteria, see: Rossiter, C. L., 1948, pp. 298-306. See also: Friedrich, C. J., 1968, Constitutional Government and Democracy - Theory and Practice in Europe and America, Fourth Edition, Waltham, Massachusetts, Toronto, London, Blaisdell Publishing Company (A Division of Ginn and Company), p. 581. 
A more contemporary overview of the same issue reveals, however, that comparative constitutional law offers differing solutions to the problem. Thus, in various countries, the authority to decide on the existence of an emergency may belong either to the legislative or to the executive branch of government or even to both of them. The last mentioned solution is, for instance, present where special procedural requirements (such as prior authorization or subsequent ratification by the parliament or a governmental proposal or request for declaring an emergency) are prescribed..$^{51}$ But the problem of an appropriate "equilibrium" thereof remains active. In that context, Gross and Ní Aoláin still continue to observe that "the constitutional mechanism of institutional power sharing is designed to prevent a situation in which the organ that is to exercise emergency powers under a declared emergency is also the one authorized to declare that emergency in the first place and activate its own powers." ${ }^{2}$ On the other hand, "it is aimed at ensuring that the branch of government most capable of acting rapidly and effectively to counter a crisis is not rendered unable to take the measures that are deemed necessary to overcome the particular exigency." 53

The Croatian solution actually gives the Government an almost unrestrained power to decide both on the introduction and termination of the state of epidemic. ${ }^{54}$ According to the Infectious Diseases Protection Law, the epidemic is declared by the government, upon the proposal of the Minister of Health, or, in the case of a danger of an epidemic, by the Minister of Health, upon the proposal of the Croatian Institute for Public Health. ${ }^{55}$ At the same time, the Law does not prescribe any time limitations on the duration of the state of epidemic nor does it impose that its existence should be legally reviewed within some fixed period. On the other hand, the Law on the Civil Protection System, which introduced the "special circumstances" regime designed particularly for the purpose of dealing with the Covid-19 epidemic, contains no rule whatsoever as to who has the authority to declare that special circumstances actually exist. The same goes for their duration. In practice, the existence of special circumstances is decided by the National Civil Protection Headquarters, but

51 For a general overview of the issue, see: Gross, O., Ní Aoláin, F., 2006, pp. 57-58.

52 Ibid., pp. 57-58.

53 Ibid., p. 58.

54 In this context, the Constitutional Court also deferred to the legislative framework, arguing that anti-epidemic measures may last no longer than the epidemic itself. Decision of the Croatian Constitutional Court: U-I-1372/2020, September $14^{\text {th }} 2020$. It should be stressed, however, that in practice the National Headquarters enacts specific measures only for a limited period and extends their duration where necessary.

55 The Infectious Diseases Protection Law, Article 2, paras. 4 and 5. 
this body is, at the same time, empowered to enact special anti-epidemic measures. Additionally, those measures are, according to the strict letter of the Law, enacted under direct control of the Government. Moreover, the Headquarters is also in its composition entirely dependent on the Government. It is headed by the Minister of the Interior while other members are appointed by the Government, in vast majority as the representatives of various state ministries.

Obviously, the foregoing doctrinal warnings on the need to separate authority to decide on the existence of an emergency and powers to be used in such case are not respected. But this is the actual scheme under which the Croatian authorities are dealing with the present epidemic. Also, I have already emphasized that the majority in the Constitutional concluded that the issue of proclamation of an emergency is beyond the review powers of the Court and that it, as a kind of a political question, rests entirely in the hands of the Parliament. ${ }^{56}$

\subsubsection{Emergency "law-making" powers}

Conferring the law-making power on the executive is not an unusual consequence of emergency models. Once again, the comparative perspective reveals that this may be done in various ways: explicitly by constitution, delegation of some powers through specific and temporary legislation, broader delegation of powers, an enabling act or permanent legislation. ${ }^{57}$ However, history shows that grave crises may well produce enormous delegation of powers to the executive. This, however, may subsequently turn out to be quite problematic in further determining the exact scope and purpose of what really was meant to be delegated. .8

It is exactly in this context that some authors point to practice and argue the following:

Legislators themselves know that Congress is not well suited for emergency action. Rather than trying to legislate for emergencies during emergencies, legislators act beforehand, authorizing the president and executive agencies to act if an emergency arises and generally granting them massive discretion. Legislative action during emergencies consists predominantly of ratification of what the executive has done, authorizations

56 Decision of the Croatian Constitutional Court: U-I-1372/2020, September $14^{\text {th }} 2020$.

57 See generally: Gross, O. and Ní Aoláin, F., 2006, pp. 59-60.

58 Notable historical examples of broad delegation of power to the executive include, for instance, the English 1914 Defense of the Realm Act and the 1914 French enabling. Ibid., pp. 29-30, 181-183 and 233-234. See also: Rossiter, C. L., 1948. More recent comparable example of a broad delegation of power may include the American 2001 Authorization for Use of Military Force. 
of whatever it says needs to be done, and appropriations so that it may continue to do what it thinks is right. Aware of their many institutional disadvantages [...] legislators confine themselves to expressions of support or concern. ${ }^{59}$

Nonetheless, the rule of law principle would, I believe, require that law-making powers of the executive are subject to rather strict limitations in terms of clarity of a mandate given for that purpose, foreseeability of measures that may be adopted, some type of (periodical) review from an external (representative body) or limited time duration. This, of course, would also be the case where no real emergency is proclaimed and where no other constitutional emergency checks are in place. ${ }^{60}$

I have already pointed to the problem that in Croatia the current anti-epidemic measures are enacted by the National Civil Protection Headquarters, a body which is under direct control of the Government. From that point of view, the Headquarters enacts specific measures only after they have previously been discussed in the Cabinet and although so far none of them was subsequently invalidated by the Government, it is quite clear that such a solution is at table, should the case require it. It must be admitted that the Headquarters was adopting its measures so far for only limited periods of time, albeit often with further extensions. ${ }^{61}$ Nevertheless, there still are some concerns to be addressed here.

The first one relates to the fact that the power to enact special anti-epidemic measures is defined quite vaguely. As I pointed earlier, according to the Law on the Civil Protection System the National Civil Protection Headquarters has a broad mandate to render decisions and guidelines for the purpose of protecting the lives and health of citizens. No more precise guideline as to what those measures may amount to is given in the said act. On the other hand, the Infectious Diseases Protection Law is in that context more concrete and it enumerates and defines specific measures, but it also contains a general clause allowing for the adoption of all other necessary measures. ${ }^{62}$ The majority in the Constitutional Court did not

59 Posner, E.A., Vermeule, A., 2007, p. 47.

60 Once again, I stress that this is the exact case in Croatia, where no emergency regime under Article 17 of the Constitution was introduced. Had it been used, a qualified parliamentary two-thirds majority would have the exclusive power to decide on new limitations of constitutional rights and freedoms, save for the case where the Parliament would not be able to meet. In the latter situation, the Government would, however, need to decide on the same matter jointly with the President of the Republic.

61 All the COVID-19 measures of the National Civil Protection Headquarters are available (in Croatian) at: https://civilna-zastita.gov.hr/odluke-stozera-civilne-zastite-rhza-sprecavanje-sirenja-zaraze-koronavirusom/2304, 16. 4. 2021.

The Infectious Diseases Protection Law, Article 47. 
object to the legal definition of powers given to the Headquarters, but the dissenting judges concluded that the overall and temporally indeterminate "delegation" of powers contained in Article 22.a of the Law on the Civil Protection System resulted in the Headquarters becoming a "parallel legislator headed by the Minister of Interior". The dissenters also criticized the composition of the Headquarters, especially its lack of experts, concluding that it made it a "Clone of the Government".63

The second and, in my view, even more important problem is only visible from a broader perspective to the whole situation. As it can be seen, the described legislative model of anti-epidemic powers in Croatia allows the Government to, indirectly, introduce a wide range of measures affecting constitutionally protected rights and freedoms. Moreover, it can do so without much procedural or substantive limitations. From the perspective of the Government itself this is, of course, a very advantageous position because it is not restrained by other concepts that are embedded into the Croatian Constitution. Two points may be made here.

On one side, since no real emergency in terms of proclamation of a severe natural disaster was made, the Government is not bound to follow the parliamentary standings on which new measures restricting constitutional rights are possible. It is also worth emphasizing again that, should that have been the case, the Government would not have been able to pursue its own policy through its own parliamentary majority. This is because in the case of activation of Article 17 of the Constitution, the two-thirds majority for adoption of new legislative measures affecting rights is indispensable.

On the other side, the Government is neither confined within the boundaries of ordinary delegation of powers, a constitutional institution it actually tried to invoke in the first stage of the epidemic, back in March of 2020. When the news that the Government could ask for such an approach reached the parliamentary representatives, it was fiercely rejected by the opposition and the plan was instantly abandoned. However, as it turned out, this actually came as even better solution for the Government, because the Croatian Constitution expressly forbids that regulation (or restriction) of constitutional rights, among other things, may not be done through delegated powers. ${ }^{64}$

63 Decision of the Croatian Constitutional Court: U-I-1372/2020, September $14^{\text {th }} 2020$.

64 In fact, Article 88 of the Croatian Constitution prescribes that the "Parliament may authorize the Government of the Republic of Croatia, for a maximum period of one year, to regulate by decrees certain issues within its competence, except those relating to the elaboration of the constitutionally defined human rights and fundamental freedoms, national rights, the electoral system, the organization, authority and 


\subsubsection{Parliamentary overview of executive emergency actions}

The usual and most common understanding is that emergencies open the door for a more active role of the executive than it is the case in normal times. Legal outcome of such a position is, as I have already pointed, a concentration of crisis powers in the hands of the executive branch of government.

Logical consequence of such understanding is that possible control of emergency dealings remains with the two remaining branches ${ }^{65}$ and constitutional doctrine agrees that there are two instances that are designed to curb the emergency executive action: the judicial review mechanism and the separation of powers mechanism. ${ }^{66}$ Moreover, the separation of powers mechanism may, in principle, influence the executive either through an ex ante or through an ex post statutory authorization. ${ }^{67}$

Those who criticize that parliaments can have any substantial role in reviewing executive emergency actions often use similar type of arguments. For instance, that popular assemblies are unfit for a quick and decisive action required in crises, that their deliberations take precious time, that they do not dispose of relevant information, which change rapidly, that political debates burden the whole process at the expense of efficiency and so on. This, at the same time, opens the door for arguing that it is the executive branch which should have primacy when an emergency occurs.

Actually, arguments in favor of such interpretations were framed rather early in history. Thus, for instance, it was already John Locke who warned that "in some governments the law-making power is not always in being, and is usually too numerous, and so too slow for the dispatch requisite to execution." ${ }^{8}$ Consequently: "it is impossible to foresee, and so by laws to provide for all accidents and necessities that may concern

operation of government bodies and local self-government." In addition, those decrees cannot have a retroactive effect and "shall cease to be valid after the expiry of the period of one year from the date when such authority was granted, unless otherwise decided by the Croatian Parliament." Obviously, such a solution, as compared to the "special circumstances" model, would be much less beneficial to the Government.

65 For a classical view that emergency measures may be controlled by parliaments and courts, see, for instance: Camus, G., 1965, L'État de nécessité en démocratie, Librairie générale de droit et de jurisprudence, Paris, p. 337 and further. See also: Gross, O., Ní Aoláin, F., 2006, pp. 62-66.

66 Tushnet, M., 2005, pp. 2673-2674. For the same division into the judicial review and separation of powers mechanism, see also: Gross, O. i Ní Aoláin, F., 2006, p. 63.

67 Posner, E. A. and Vermeule, A., 2007, pp. 161-163.

68 Locke, J., 1824, Two Treatises on Government, CHAPTER XIV. (Of prerogative.), $\$ 160$. In: The Works of John Locke in Nine Volumes, $12^{\text {th }} \mathrm{ed}$. Vol. 4 , London, Rivington. 
the public, or to make such laws as will do no harm, if they are executed with an inflexible rigour on all occasions, and upon all persons that may come in their way; therefore there is a latitude left to the executive power, to do many things of choice which the laws do not prescribe." 69 Comparably, Hamilton stressed that

Energy in the Executive is a leading character in the definition of good government. It is essential to the protection of the community against foreign attacks [...] Decision, activity, secrecy, and despatch will generally characterize the proceedings of one man in a much more eminent degree than the proceedings of any greater number; and in proportion as the number is increased, these qualities will be diminished. ${ }^{70}$

Echoes of such position are traceable to modern times and are visible with modern American executive unilateralists who, for instance, continue to insist that the executive acts like a "unitary, rational actor" which can most properly "identify threats, develop responses, evaluate costs and benefits, and seek to achieve national strategic goals through value-maximizing policies and actions." 71 Executive qualities of "the unity of office, its capacity for secrecy and dispatch, and its superior sources of information" as well as the fact that, unlike the Congress, it is "always on and ready for action", just further fuel the argument that it represents the right branch to do the job. ${ }^{72}$

The case to defend the position of parliaments becomes even harder if one points to the 'rally 'round the flag' phenomenon, often present in times immediately following the emergence of crisis and resulting in parliamentary giving the executive a wide range of powers seen as necessary to address the threat. Here, not only the advantages of an expedient executive are emerging, but it may also happen that the ordinary party politics divisions, usual for normal times, are set aside. ${ }^{73}$

This last mentioned pattern is clearly visible in the Croatian case where the parliament was extremely quick in amending the Law on the Civil Protection System in order to enable the National Civil Protection Headquarters to render decisions and guidelines for the purpose of protecting the lives and health of citizens. I have already pointed to several problems such a scheme produces but it is also worth mentioning that the amendment was made merely seven days after the formal proclamation

69 Ibid.

70 Hamilton, A., 1788, The Executive Department Further Considered, Federalist, No. 70, March 18.

71 Yoo, J., 2006, The Powers of War and Peace - the Constitution and Foreign Affairs after 9/11, Chicago, London, The University of Chicago Press, p. 20.

72 Ibid.

73 Gross, O., Ní Aoláin, F., 2006, pp. 64-65. 
of the epidemic and that more than two-thirds of all the parliamentary representatives voted for its enactment. As the epidemic continued, there followed other adjustments to both the said Law and the Infectious Diseases Protection Law, but so did the parliamentary calls to put the executive under a more stringent control. These principally came as requests for the Government to issue frequent reports on the exact measures it was adopting and the general anti-epidemic strategy it was pursuing. However, and taking into account the absence of a formally proclaimed emergency which would give the parliamentary opposition the tool for a harder pressure, the result thereof is quite modest. What the Parliament, under the ruling coalition, actually adopted is a "conclusion" that the Croatian Government is obliged to report on its Covid-19 related measures merely three times a year. ${ }^{74}$ So far, only the first such general report was issued. ${ }^{75}$ In addition, it is worth noticing that the Infectious Diseases Protection Law prescribes that the Ministry of Health is obliged to carry out a subsequent verification of the effects of the Law, but only after two years have passed since the 2020 anti-epidemic amendments to it were enacted.

The Parliament, however, did reject some governmental requests for more expansive authorizations. Apart from the idea to invoke the delegation of powers I have already mentioned, a notable example was a governmental bill to amend the Law on Electronic Communications. The purpose of that amendment was to allow for locating mobile phones for the purpose of carrying out the activities of civil protection in circumstances of epidemic, but the idea provoked strong criticism and was abandoned in the midst of a legislative procedure.

The Croatian Constitutional Court, finally, pointed that in the present epidemic the Parliament still retains its general powers to exert ordinary control through a possibility to open the procedure of voting on confidence to the Government. It also emphasized relevance of a possibility for the Parliament to ask for special reports, the fact that the Headquarters was indirectly, via the Government, accountable to the Parliament and that the anti-epidemic measures were in all times subject to constitutional review. ${ }^{76}$

74 The Conclusion of the Croatian Parliament adopted on $4^{\text {th }}$ December 2020.

75 The Report on the Effects of Measures Implemented on the Basis of the Infectious Diseases Protection Law During the COVID-19 Epidemic for the Period Between $11^{\text {th }}$ March 2020 and $15^{\text {th }}$ January 2021. The Report was submitted by the Government on $18^{\text {th }}$ January 2021 and covers the period of almost a year.

76 Decision of the Croatian Constitutional Court: U-I-1372/2020, September $14^{\text {th }} 2020$. The dissenters in this case, however, strongly objected to the fact that the National Civil Protection Headquarters, unlike the Minister of Health, was not directly accountable to the Parliament. 


\subsubsection{The issue of parliamentary sittings}

Naturally, parliamentary overview of executive emergency actions is possible only where the parliament is not effectively prevented to perform its constitutional duties. In practice, this means that in crisis it should be convened as much as possible. This is also in line with Rossiter's point that "the dictatorship should be carried on by persons representative of every part of the citizenry interested in the defense of the existing constitutional order" ${ }^{\prime 7}$ Some modern constitutions, for that purpose, prescribe that in emergencies parliaments either cannot be dissolved or that in such periods their term of office is automatically extended. ${ }^{78}$ And if the claim goes that the situation is rather ordinary, the argument in favor of normal operation of a legislative assembly is even stronger.

Thus, as an additional argument in favor of my claim that in circumstances of the present epidemic the Government concentrates its powers, I highlight one fact related to the actual organization of parliamentary sittings. Following the spread of the epidemic and an evident potential threat to the health of parliamentary representatives, the Standing Orders of the Croatian Parliament were in 2020 amended in several important aspects. ${ }^{79}$ Those amendments, on one hand, allowed for electronic means of communication and voting, while on the other they reduced the number of representatives allowed to be present in the parliamentary hall during debates, as well as the time of their expositions and number of their repliques. The troubling part of the story is that this special mode of operation of the Parliament, its introduction, duration and termination is completely depending upon the decision made by the presidency of the Parliament alone and not by the entirety of representatives. Moreover, from the procedural point of view, the presidency of the Parliament may introduce and terminate the special mode of operation only according to the governmental decision declaring an epidemic or its termination. ${ }^{80}$ Of course, it must be stressed that the presidency as a special body reflects only a significantly reduced representation of parliamentary representatives and is dominated by the ruling majority.

Unfortunately, this specific problem was not even addressed by the Croatian Constitutional Court when it reviewed the said Standing Orders in October 2020. ${ }^{81}$

77 Rossiter, C. L., 1948, p. 304.

78 Gross, O., Ní Aoláin, F., 2006, p. 61.

79 Article 293.a of the Standing Orders of the Croatian Parliament.

80 An analogue situation exists in case of declaration of the danger of epidemic, which is made by the Minister of Health.

81 Decision of the Croatian Constitutional Court: U-I-4208/2020, October $20^{\text {th }} 2020$. The Constitutional Court, however, did struck down those part of the Standing 


\section{Conclusion}

I already stressed several times here that the current Croatian model of combating the Covid-19 epidemic is constructed as a legislatively based model. Accordingly, despite the invocation of "special circumstances", it gives an impression of "legal normalcy". This is, moreover, especially visible in the fact that in Croatia no constitutional rules regarding the apparition of a "severe natural disaster" (an "emergency" regime) were invoked.

However, following the short analysis I tried to offer in the preceding chapters, the actual case in constitutional terms is far away from normalcy. This is best seen in various legal consequences arising from the situation, as it is, in which one may clearly notice important elements of the concentration of powers in the hands of the executive. Various concerns may be raised in that context.

The first is that there exists no clear separation of powers of declaring an exceptional situation and of powers for enacting special measures. The second is that the executive has a broad mandate in law-making, including the power to directly and effectively restrict constitutionally protected rights and freedoms. The third is that the legislative branch may control the special undertakings of the executive only in a very limited way. And the fourth is that the legislature in its own processes of deliberation and decision-making is significantly dependent on the executive.

Undoubtedly, emergencies create consequences, in people's lives, in social and economic relations, and in constitutional law. The present epidemic makes no exception here. However, one must also ask whether those consequences justify the concrete legal model chosen in a given situation. Surely, it would be naïve to claim that such a dangerous threat, as is the corona virus, could completely be reacted to without some temporary and special measures or even some readjustments in the field of legislation. But when the threat is global, or when one claims that it is novel and unprecedented, it should also be accepted that its consequences might go well far beyond what is expected in a "normal" situation.

My criticism of the current Croatian model of dealing with the epidemic focuses exactly on these points. In very concrete terms, I believe that a far better solution for the country would have been if the authorities had accepted the reality and referred to what they should have: the model of a "severe natural disaster" contained in Article 17 of the Croatian Constitution.

Orders which allowed only for electronic communication within parliamentary committees and not for the entirety of representatives in plenary sessions. 
Had that been the case, the authority to proclaim a state of a severe natural disaster, which belongs to the two-thirds majority in the Parliament, would be more clearly separated from the authority to undertake special measures. Moreover, the authorized executive bodies (Minister of Health and the National Civil Protection Headquarters) could proceed to apply measures already contained in the existing legislation whereas demands for more restrictions on constitutionally protected rights and freedoms would have to be confirmed by the legislature. This also means that the Parliament would have more control of the executive special actions in the most precious domain: the one affecting rights and freedoms. In addition, and needless to say, the decision to activate Article 17 of the Constitution and thus to accept that two-thirds majority in the Parliament was needed to combat the epidemic would just further strengthen democratic legitimacy indispensable in a scenario where the threat is global, unprecedented and very much possibly of a more permanent nature.

Instead of that, and especially having in mind that the whole Covid-19 story has lasted for more than a year now, the ongoing Croatian approach to the epidemic starts to resemble the "Business as Usual" paradigm. However, at the time of my writing (April 2021) there is, unfortunately, still no solid ground for concluding that the pandemic will soon end. And this is exactly where my final concern I wish to point to at this occasion resides: that the "special circumstances" model makes it quite difficult to properly separate normalcy and emergency.

\section{BIBLIOGRAPHY}

1. Ackerman, B., 2006, Before the Next Attack - Preserving Civil Liberties in an Age of Terrorism, New Haven, London, Yale University Press.

2. Ackerman, B., 2004, The Emergency Constitution, Yale Law Journal, 113.

3. Agamben, G., 2005, State of Exception, Chicago, London, The University of Chicago Press.

4. Camus, G., 1965, L'État de nécessité en démocratie, Paris, Librairie générale de droit et de jurisprudence.

5. Ferejohn, J., Pasquino, P., 2004, The Law of the Exception: A Typology of Emergency Powers, International Journal of Constitutional Law, Vol. 2, No. 2.

6. Friedrich, C. J., 1968, Constitutional Government and Democracy - Theory and Practice in Europe and America, Fourth Edition, Waltham, Massachusetts, Toronto, London, Blaisdell Publishing Company (A Division of Ginn and Company).

7. Gardasevic, Dj., Activism of the Croatian Constitutional Court and COVID-19: A Bridge Too Far, in: Belov, M., (ed.), Courts and Judicial Activism Under Crisis Conditions - Policy Making in a Time of Illiberalism and Emergency Constitutionalism, Routledge (forthcoming on September $23^{\text {rd }} 2021$ ). 
8. Gardašević, Đ., Izvanredna stanja, “velike prirodne nepogode” i promjene Ustava Republike Hrvatske, in: Ustavne promjene i političke nagodbe - Republika Hrvatska između ustavne demokracije i populizma, Bačić, A. (ed.), 2021, Zagreb, Hrvatska akademija znanosti i umjetnosti - Znanstveno vijeće za državnu upravu, pravosuđe i vladavinu prava.

9. Gardašević, Đ., Pandemija kao “stanje velike prirodne nepogode” i Ustav Republike Hrvatske, in: Barbić, J. (ed.), 2021, Primjena prava za vrijeme pandemije COVID-19, Zagreb, Hrvatska akademija znanosti i umjetnosti - Znanstveno vijeće za državnu upravu, pravosuđe i vladavinu prava.

10. Greene, A., States should declare a State of Emergency using Article 15 ECHR to confront the Coronavirus Pandemic, (https://strasbourgobservers. com/2020/04/01/states-should-declare-a-state-of-emergency-using-article-15echr-to-confront-the-coronavirus-pandemic/, 13. 4. 2021).

11. Grogan, J., Power and the COVID-19 Pandemic - Introduction \& List of Country Reports, VerfBlog, 2021/2/22, (https://verfassungsblog.de/power-and-the-covid19-pandemic/, DOI: 10.17176/20210222-154018-0).

12. Grogan, J., Introduction \& List of Country Reports, VerfBlog, 2020/4/06, (https://verfassungsblog.de/introduction-list-of-country-reports/, DOI: 10.17176/20200417182630-0).

13. Gross, E., 2008, How to Justify an Emergency Regime and Preserve Civil Liberties in Times of Terrorism, South Carolina Journal of International Law and Business, Vol. 5, Issue 1.

14. Gross, O., Ní Aoláin, F., 2006, Law in Times of Crisis - Emergency Powers in Theory and Practice, New York, Cambridge University Press.

15. Hamilton, A., 1787, The Necessity of a Government as Energetic as the One Proposed to the Preservation of the Union, Federalist, No. 23, December 18.

16. Hamilton, A., 1788, The Executive Department Further Considered, Federalist, No. 70, March 18.

17. Locke, J., 1824, The Works of John Locke in Nine Volumes, $12^{\text {th }}$ ed., Vol. 4, London, Rivington.

18. Madison, J., 1788, The Powers of the Convention to Form a Mixed Government Examined and Sustained, Federalist, No. 40, January 18.

19. Omejec, J., 2020, Primjena Europske konvencije o ljudskim pravima u doba koronavirusa, Informator - tjednik za pravna i ekonomska pitanja, 68, No. 6622.

20. Özbudun, E., Turhan, M., 1995, Emergency Powers, European Commission for Democracy Through Law, Council of Europe Publishing.

21. Posner, E. A., Vermeule, A., 2007, Terror in the Balance - Security, Liberty and the Courts, New York, Oxford University Press.

22. Posner, R. A., 2006, Not a Suicide Pact - the Constitution in a Time of National Emergency, New York, Oxford University Press.

23. Rosenfeld, M., A Pluralist Theory of Political Rights in Times of Stress, in: Sadurski, W., (ed.), 2006, Political Rights under Stress in $21^{\text {st }}$ Century Europe, Oxford, New York, Oxford University Press.

24. Rosenfeld, M., 2006, Judicial Balancing in Times of Stress: Comparing the American, British, and Israeli Approaches to the War on Terror, Cardozo Law Review, Vol. 27:5. 
25. Rossiter, C. L., 1948, Constitutional Dictatorship - Crisis Government in the Modern Democracies, Princeton, Princeton University Press.

26. Rousseau, J. J., 1951, The Social Contract, New York, The Hafner Library of Classics, Hafner Publishing Company.

27. Scheinin, M., COVID-19 Symposium: To Derogate or Not to Derogate?, (http:// opiniojuris.org/2020/04/06/covid-19-symposium-to-derogate-or-not-to-derogate/, 13. 4. 2021).

28. Scheppele, K. L., 2006, Small Emergencies, Georgia Law Review, 40.

29. Scheuerman, W. E., 2006, Emergency Powers and the Rule of Law After 9/11, The Journal of Political Philosophy, Vol. 14, No. 1.

30. Schmitt, C., 2005, Political Theology, Four Chapters on the Concept of Sovereignty, Chicago, University of Chicago Press.

31. Selanec, Nika Bačić: Croatia’s Response to COVID-19: On Legal Form and Constitutional Safeguards in Times of Pandemic, VerfBlog, 2020/5/09, (https://verfassungsblog.de/croatias-response-to-covid-19-on-legal-form-and-constitutionalsafeguards-in-times-of-pandemic/, DOI: 10.17176/20200509-133132-0).

32. Selanec, Nika Bačić: COVID-19 and the Rule of Law in Croatia: Majoritarian or Constitutional Democracy?, VerfBlog, 2021/4/27, (https://verfassungsblog.de/ covid-19-and-the-rule-of-law-in-croatia-majoritarian-or-constitutional-democracy/, DOI: 10.17176/20210427-101228-0).

33. Tushnet, M. (ed.), 2005, The Constitution in Wartime - Beyond Alarmism and Complacency, Duke, London, Duke University Press.

34. Yoo, J., 2006, The Powers of War and Peace - The Constitution and Foreign Affairs after 9/11, Chicago, London, The University of Chicago Press.

\section{Case Law (Croatian Constitutional Court)}

1. U-I-1372/2020, September $14^{\text {th }} 2020$.

2. U-I-2162/2020, September $14^{\text {th }} 2020$.

3. U-II-1312/2020, September $14^{\text {th }} 2020$.

4. U-II-2027/2020, September $14^{\text {th }} 2020$.

5. U-II-1373/2020, September $14^{\text {th }} 2020$.

6. U-II-3170/2020, September $14^{\text {th }} 2020$.

7. U-I-1925/2020, September $14^{\text {th }} 2020$.

8. U-II-2379/2020, September $14^{\text {th }} 2020$.

9. U-I-4208/2020, October $20^{\text {th }} 2020$.

10. U-I-5918/2020, U-I-5919, February $3^{\text {rd }} 2021$.

11. U-II-5709/2020, U-II-5788/2020, February $23^{\text {rd }} 2021$.

12. U-II-6087/2020, U-II-6160/2020, February $23^{\text {rd }} 2021$.

13. U-II-364/2021, February $23^{\text {rd }} 2021$. 


\section{INTERNET SOURCES}

1. The speech of the Croatian Prime Minister given at the $220^{\text {th }}$ session of the Government, held on March $26^{\text {th }} 2020$. Available (in Croatian) (https://vlada.gov.hr/ vijesti/ovo-je-kriza-bez-presedana-nastavljamo-s-primjerenim-mjerama-da-zaustavimo-pandemiju/29087, 15. 4. 2021).

2. Statement given by the Croatian Prime Minister during the session of the Parliament held on November $3^{\text {rd }} 2020$. Available (in Croatian) (https://www.novilist. $\mathrm{hr} /$ novosti/hrvatska/plenkovic-zivimo-u-godini-bez-presedana-sve-se-mijenjaiz-korijena/, 15. 4. 2021).

3. https://www.telegram.hr/politika-kriminal/milanovic-se-danas-prvi-put-ozbiljno-suprotstavio-vladinoj-odluci-zapelo-je-na-ljudskim-slobodama/ (16. 4. 2021).

4. Statement given by the Croatian Prime Minister during the session of the Parliament held on April $14^{\text {th }}$ 2021. Available (in Croatian) (https://lider.media/poslovna-scena/hrvatska/plenkovic-u-saboru-brani-nacionalni-plan-oporavka-i-otpornosti-136245, 15. 4. 2021).

5. The Bill on the Amendments to the Infectious Diseases Protection Law, submitted to the Croatian Parliament on April $9^{\text {th }}$ 2020. Available (in Croatian) (https:// sabor.hr/sites/default/files/uploads/sabor/2020-04-09/183402/PZ_921.pdf, 15. 4. 2021).

6. The Bill on the Amendments to the Law on the Civil Protection System, submitted to the Croatian Parliament on March $17^{\text {th }} 2020$. Available (in Croatian) (https:// www.sabor.hr/sites/default/files/uploads/sabor/2020-03-17/183002/PZ_860.pdf, 15. 4. 2021).

7. Report on the Effects of Measures Implemented on the Basis of the Infectious Diseases Protection Law During the COVID-19 Epidemic for the Period Between $11^{\text {th }}$ March 2020 and $15^{\text {th }}$ January 2021.

8. COVID-19 measures of the National Civil Protection Headquarters (in Croatian) (https://civilna-zastita.gov.hr/odluke-stozera-civilne-zastite-rh-za-sprecavanje-sirenja-zaraze-koronavirusom/2304, April $16^{\text {th }} 2021$ ).

9. UN News: COVID-19 pandemic, an 'unprecedented wake-up call' for all inhabitants of Mother Earth, (https://news.un.org/en/story/2020/04/1062322, April $\left.15^{\text {th }} 2020\right)$. 


\title{
„NEREDOVITO STANJE“: PANDEMIJSKA KONCENTRACIJA EGZEKUTIVNIH OVLASTI U HRVATSKOJ
}

\author{
Đorđe Gardašević
}

\section{APSTRAKT}

Suočene s pandemijom Covida-19, države širom svijeta usvojile su niz specijalnih mjera. Dok su neke u tu svrhu posegnule za ustavnim normama o izvanrednim stanjima, druge su djelovale kroz zakonodavstvo. Autor tvrdi da učinci zakonodavnog pristupa epidemiji u Hrvatskoj zapravo odgovaraju stanju nužnosti u pravom smislu riječi, iako javna vlast pokušava cijeli slučaj prikazati kao stanje „pravne normalnosti“. Preciznije, autor tvrdi da usvojeni model u praksi proizvodi koncentraciju ovlasti u rukama egzekutivne grane vlasti u mjeri koja daleko prelazi ono što se može očekivati u redovnom stanju. Da bi to dokazao, autor analizira hrvatski anti-epidemijski okvir kroz nekoliko elemenata (deklaracija izvanrednog stanja, zakonodavne ovlasti, nadzor na egzekutivnim izvanrednim mjerama, zasjedanje parlamenta). Konačno autor tvrdi da je u Hrvatskoj trebalo proglasiti ustavno predviđeno stanje velike prirodne nepogode.

Ključne riječi: Covid-19, pandemija, epidemija, izvanredna stanja, Hrvatska.

Article History:

Received: 7 May 2021

Accepted: 11 June 2021 